\title{
The Effects of Prebaiting Live Traps on Catching Woodland Rodents
}

\author{
John GURNELL
}

\begin{abstract}
Gurnell J., 1980: The effects of prebaiting live traps on catching woodland rodents. Acta theriol., 25, 20: 255-264 [With 2 Tables \& 3 Figs.].

The effects on catches of woodland rodents of prebaiting Longworth live traps for varying lengths of time were investigated in fifteen different studies over a three year period. Differences in trap response between Apodemus sylvaticus, A. flavicollis and Clethrionomys glareolus were observed. The effect of prebaiting was most pronounced in $A$. flaricollis although the data were few and least pronounced in A. sylvaticus. In the main, the effect of prebaiting for one night was equally as effective as prebaiting for two. The results have been discussed with respect to sampling effort and efficiency in estimating population numbers.

[Dept. Zool., Westfield College, Univ, London, London, NW3 7ST, England].
\end{abstract}

\section{INTRODUCTION}

It has clearly been shown that the presence of an appropriate bait at a Longworth trap greatly enhances the probability of capture of woodland rodents and further, that the presence of bait is necessary if estimations of population size are required ( $\mathrm{G} u \mathrm{r} n \mathrm{ell}, 1976)$. An additional technique frequently employed in small mammal field studies is that of prebaiting; here bait is placed at the trap (or trapping station) from one to several dayls before the traps are set (eg. S m ith, Gardner et al., 1975). Chitty \& Kempson (1949) pointed out that prebaiting traps allows more, if not all, of the population to locate and become familiar with the traps before trapping commences. This, in turn, should minimise bias in the initial samples which may result from intra and interspecific variations in activity patterns and trap reaction. There have been several studies on the effects of prebaiting kill traps on the catches obtained (e.g. B a binska \& Bock, 1969; Gentry et al., 1968; Grodziński et al., 1966; Tanaka \&. Kanamori, 1969; Zejda \& Holišova, 1971) but only a few investigators have studied the effects of prebaiting live traps (e.g. Tanaka, 1970; Trojan \&. Wojciechowska, 1967). This paper reports on 
a series of studies on the effects of prebaiting Longworth traps on the capture of woodland rodents.

\section{METHODS}

The trapping studies were carried out in a mature oak woodland in Alice Holt Forest, Surrey (see Gurne11, 1978b). Longworth traps were used and contained hay bedding and whole oats as food. Prebaited traps had their doors fixed in the open position and whole oat bait scattered in and around the trap entrances (see Chitty \& Kempson, 1949; Gurnel1, 1976).

The trapping programme was organised so that one third of the traps used in any one study were placed in position and prebaited for two nights (called traps of type $\left.P_{2}\right)$ one third for one night $\left(P_{1}\right)$ and the remaining third were not prebaited at all $\left(P_{0}\right)$. All the traps were checked for efficient operation and were set at the same time, and trapping was then carried out for four nights. The traps

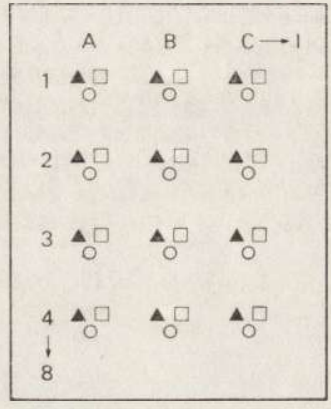

(a)

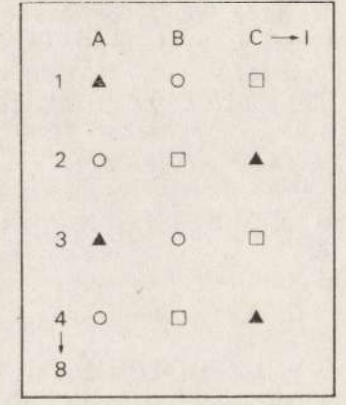

(b)

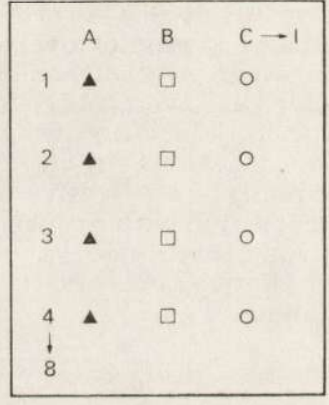

(c)

Fig. 1. Trapping patterns; different symbols represent different trap types; (a) pattern $W$, (b) pattern $X$, and (c) pattern $Y$.

Only the corners of the grids have been presented-not to scale.

were checked each morning during the prebait and trap periods and the bait replenished if necessary. The animals captured were weighed, sexed, individually toe-clipped and released.

In order to minimise the influence of small variations in the nature of the habitat, such as changing ground cover, on the catches obtained, and to eliminata the influence of trap pattern, four different patterns of traps were used. In addition, two different study. areas were used (areas $A$ and $B$ ) which were some $200 \mathrm{~m}$ apart. The trap patterns, which differed in the closeness of the different trap types, are outlined below, and three of the patterns are illustrated in Fig. 1.

Pattern $W$, area $A$ - three traps per point, about $1.5 \mathrm{~m}$ apart and each of a different type, on a grid consisting of 8 lines by 9 rows with $10 \mathrm{~m}$ spacing. The total number of traps was 216 (Fig. 1a).

Pattern $X$, area $A$ - one trap per point on the same grid as above. Adjacent traps were of a different type (see Fig. 1b). The total number of traps was 72 .

Pattern $Y$, area $B-$ one trap per point on a grid consisting of 8 lines, $10 \mathrm{~m}$ apart, by 9 rows, $15 \mathrm{~m}$ apart; different types of trap were used in each row. The total number of traps was 72 (Fig. 1c). 
Pattern $Z$, area $B$ - three different grids $30 \mathrm{~m}$ apart, consisting of 6 lines by 5 rows with $6 \mathrm{~m}$ spacing. Traps of a different type were used on each grid, the total number of traps used was 90.

Fifteen trapping studies were carried out between September 1975 and January 1979 , some of them concurrently on areas $A$ and $B$ (Table 1). The position of the different trap types was varied in subsequent studies using the same pattern of traps. Owing to cold wet conditions trapping was terminated early in studies 9 , 10 and 14. Further, not all the unmarked animals captured on nights two and three of study 12 were toe-clipped.

\section{RESULTS}

\subsection{Densities of Wood Mice and Bank Voles}

Table 1 shows the dates of the trapping studies, the trap patterns used and crude densities of wood mice, Apodemus sylvaticus (Linnaeus, 1758) and bank voles, Clethrionomys glareolus

Table 1

Trapping studies.

\begin{tabular}{|c|c|c|c|c|c|}
\hline $\begin{array}{l}\text { Study } \\
\text { No. }\end{array}$ & $\begin{array}{c}\text { Date traps } \\
\text { set }\end{array}$ & $\begin{array}{l}\text { Trap } \\
\text { pattern }\end{array}$ & $\begin{array}{l}\text { No. nights } \\
\text { trapping }\end{array}$ & $\begin{array}{l}\text { Density wood } \\
\text { mice (no/ha) }\end{array}$ & $\begin{array}{l}\text { Density bank } \\
\text { voles (no/ha) }\end{array}$ \\
\hline 1 & 14.09 .75 & W & 4 & 50 & 38 \\
\hline 2 & 30.09 .75 & W & 4 & 42 & 32 \\
\hline 3 & 31.10 .75 & $X$ & 4 & 31 & 22 \\
\hline 4 & 21.01 .76 & $X$ & 4 & 15 & 21 \\
\hline 5 & 3.05 .76 & $X$ & 4 & 6 & 7 \\
\hline 6 & 5.08 .76 & W & 4 & 14 & 28 \\
\hline 7 & 22.10 .76 & $X$ & 4 & 46 & 25 \\
\hline 8 & 22.10 .76 & $Y$ & 4 & 29 & 17 \\
\hline 9 & 17.12 .76 & W & 2 & 118 & 35 \\
\hline 10 & 17.12 .76 & $Y$ & 3 & 60 & 18 \\
\hline 11 & 3.03 .77 & $X$ & 4 & 76 & 64 \\
\hline 12 & 3.03 .77 & $Y$ & 4 & 42 & 39 \\
\hline 13 & 28.11 .78 & $Z$ & 4 & $25 *$ & $8^{*}$ \\
\hline 14 & 17.12 .78 & $Z$ & 3 & $33 *$ & 9 * \\
\hline 15 & 18.01 .79 & $Z$ & 4 & $48 *$ & $25 *$ \\
\hline
\end{tabular}

* Average densities for three grids (see text).

( $\mathrm{S} \mathrm{c} \mathrm{h} \mathrm{re} \mathrm{be} \mathrm{r,} \mathrm{1780)} \mathrm{calculated} \mathrm{from} \mathrm{the} \mathrm{number} \mathrm{of} \mathrm{individuals} \mathrm{captured}$ highest in autumn or winter and lowest in summer; the reasons for values for the three grids used in trap pattern $Z$ in each study period (see above). The results show a considerable range in densities of the rodent species over the study period. In general the numbers were highest in autumn or winter and lowest in summer; the reasons for this will be discussed elsewhere, 


\subsection{Numbers of Captures of Wood Mice and Bank Voles}

The numbers and percentage numbers of nightly totals of wood mice and bank voles captured each night are presented in Table 2 . The results of studies 3 to 8 have been pooled because of the small numbers of animals captured in each trap type in the individual studies. Studies 1 and 2 have been combined because they were carried out within two weeks of each other, and studies 9 and 10, and 11 and 12 have been combined because they were carried out concurrently. These comibined results have been analysed by the chi-square test to see whether more or less animals than expected were captured in each trap type; significant findings $(p<0.05)$ have been marked with an asterisk in Table 2.
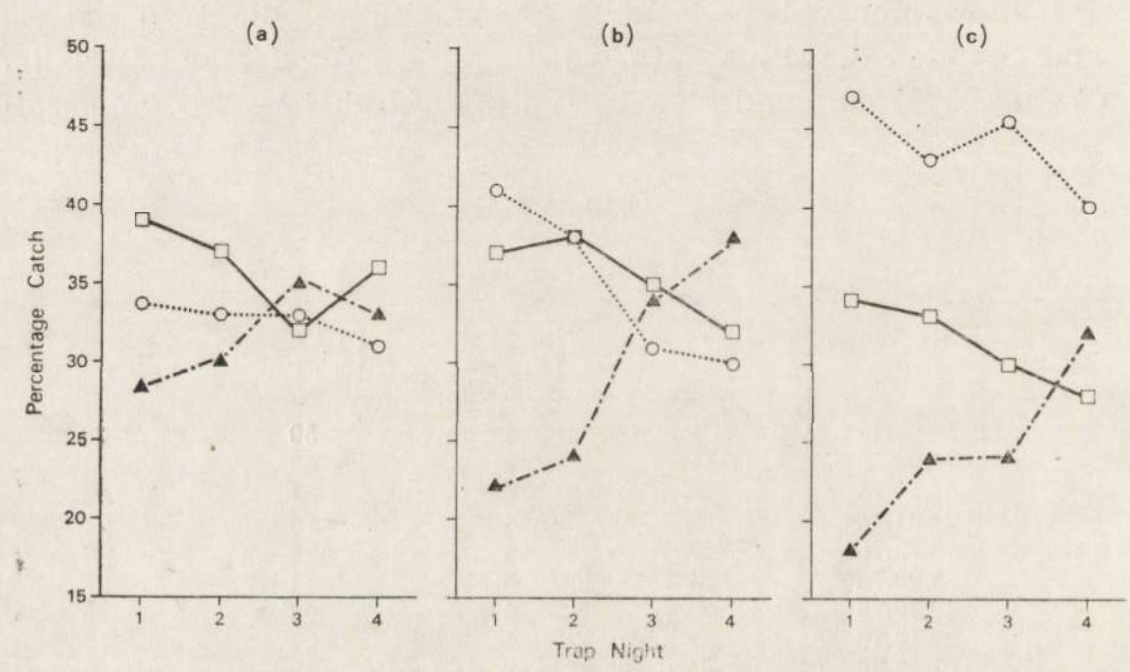

Fig. 2. The percentage numbers of nightly totals of wood mice (a), bank voles (b), and yellow-necked mice (c) captured in different trap types.

$O \rightarrow P_{2}$ traps, $\square-P_{1}$ traps, $\mathbf{A}-P_{0}$ traps (see text).

Intuitively prebaiting should have its greatest effect on catches on the first night of trapping; thereafter its influence should decline the longer the trapping period. There was considerable variation in numbers captured in each trap type on the first night of each combination of studies, particularly in voles. Overall more voles were captured in prebaited traps on night one, although the difference between $P_{2}$ and $P_{1}$ traps was slight. A significant value of chi-square was only found for the pooled data. In catching wood mice on night one, $P_{1}$ traps were slightly more effective than $P_{2}$. Here differences were only significant for studies 9 and 10 ; the reason for this is unclear, although the weather 


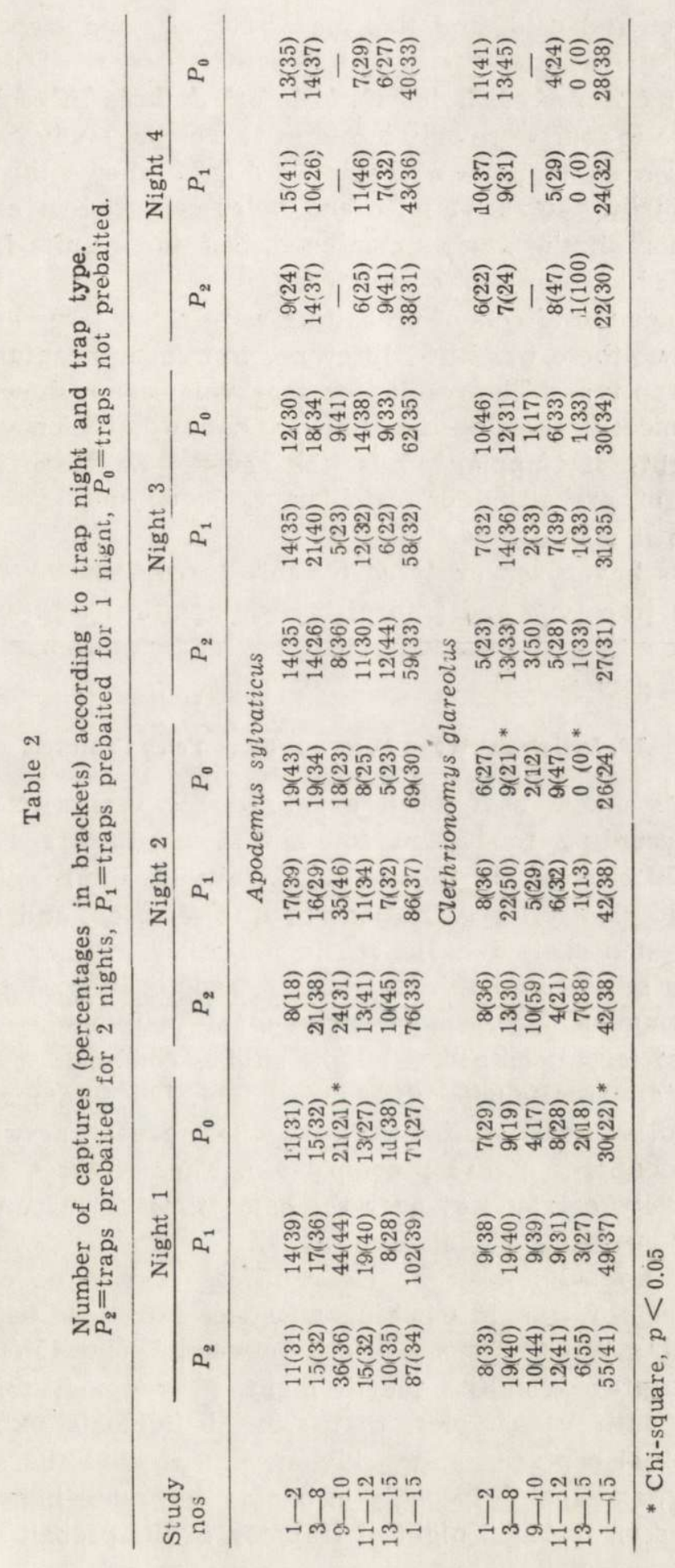


was very wet and cold, and this may have effected trap reaction at this time.

Significant differences in the number of captures in each trap type on nights two to four were only found in two of the study combinations, both for voleis on night two (Table 2). Fig. 2 shows the percentage number of nightly totals of mice and voles captured in each trap on. each night for all the studies combined, less the results from studies 9,10 and 14 which were not completed.

In wood mice the effects of prebaiting were never large and certainly after night two there was little difference in numbers captured between any of the trap types. The results for bank voles again show differences from wood mice; $P_{2}$ traps declined in their capture efficiency throughout the four nights of trapping whilst the reverse was seen in $P_{0}$ traps. The effects of prebaiting on catching voels do not appear to have been lost until night 3 .

The results have been analysed by chi-square tests for homogeneity according to trap type and trap night. No significant differences were obtained for either the trapping patterns analysed separately or for all the studies combineid.

\subsection{Individual Wood Mice and Bank Voles Captured}

The results above have been examined for variations in capture efficiency according to if and for how long the traps have been prebaited. Differences in the night of initial capture of individual animals could also reflect variations in trap reaction, and traps which have not been prebaited could act in a similar manner to prebaited traps on the second and thind nlights of trapping. Fig. 3 presents the percentage number of the total number of individuals according to their night of initial capture in all the studies combined, excluding the incomplete data from studies $9,10,12$ and 14 . The findings from other trapping studies in area $A$ of Alice Holt, where prebaiting was not used, have also been presented for comparison. These figures are from 12 trapping periods carried out over the same time period and involving similar numbers of individuals (see Fig. 3).

The prebait results show no clear differences in the efficiency of different types of trap in catching new wood mice or bank voles on trapping nights two to four. Overall, between 7 and $15 \%$ of animals were first captured on the fourth night of trapping, this indicates, particularly with bank voles, that some individuals exhibited long delays in initial capture, or possibly movement onto the study areas. Interestingly, and again especially in bank voles, more individuals were first captured on the first night of trapping in the prebait studies than 
in the non-prebait studies, and in the voles there was a bias towards prebaited traps. In bank voles, therefore, there is a suggestion, although inconclusive, that prebaiting just some traps influenced the activity and trap reaction of animals on the study areas as a whole.
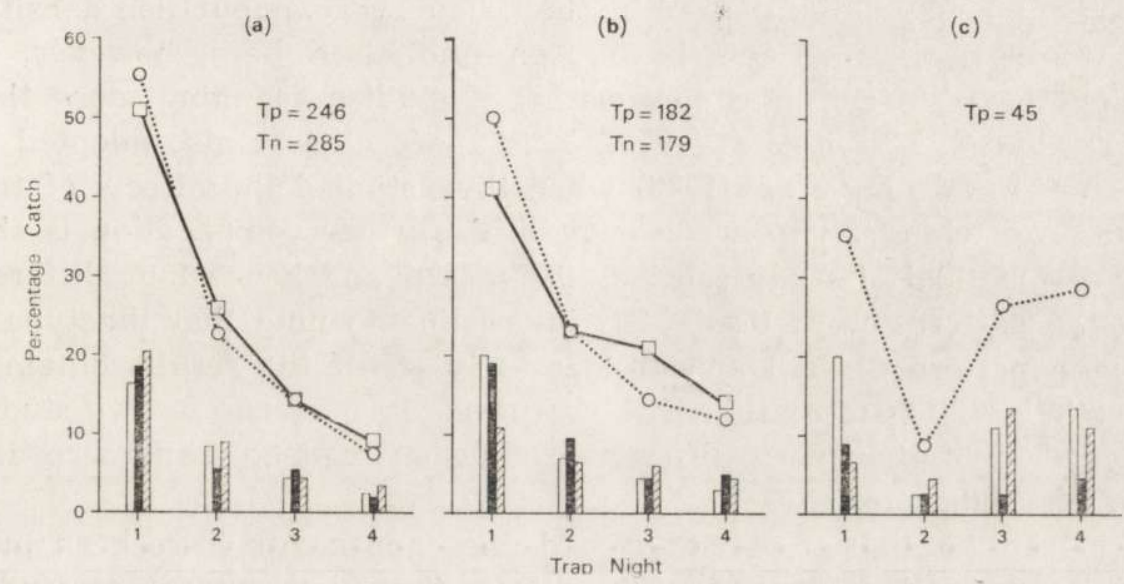

Fig. 3. The percentage number of the total number of individuals of (a) wood mice, (b) bank voles, and (c) yellow-necked mice captured on each night of trapping.

O - prebait studies, $\square$ - non-prebait studies. Bar graphs are percentages of individuals captured in each trap type on each night; unshaded $-P_{2}$ traps, shaded $-P_{1}$ traps, cross-hatched $-P_{0}$ traps, $T_{\mathrm{p}}=$ total number of individuals from the prebait studies on which the figure is based. $T_{n}=$ total number of individuals from the non-prebait studies.

\subsection{Numbers of Yellow-necked Mice Captured}

Some yellow-necked mice, A. flavicollis ( $\mathrm{Mel} \mathrm{ch}$ ior, 1834), were captured during the study period, especially on area $B$. These results have been analysed in the same way as above for all studies combined, and the results are presented in Fig. 2 (kased on a total of 138 captures) and Fig. 3 (based on 45 individuals). The data are scanty but they indicate that the behaviour of yellow-necked mice towards live traps differs from that of wood mice and bank voles. Traps prebaited for two nights were most successful in catching A. flavicollis throughout the four nights of trapping (Fig. 2) whilst $P_{0}$ treps were least successful. In addition, a considierable number of new individuals were captured on the third and fourth nights of trepping, although after the first night, there is no clear bias towards prebaited traps (Fig. 3).

\section{DISCUSSION AND CONCLUSIONS}

There are many factors which affect the trappability of small mammals (e.g. Kikkawa, 1964; Gurne 11, 1972) and it is difficult 
to study the effects of any one factor in isolation. Laboratory, confined populations and specifically designed field studies have all been used to study different aspects of the trappability of woodland rodents (e.g., Gurnel1, 1976, 1978a, 1978b). The results from field studies in particular may be influenced by the time of year, population densities and weather; these effects have been minimised here, however, by pooling the results from a long series of studies spanning more than three years (cf. T a naka, 1970). This approach was also adopted by Boonstra \& Krebs (1976) when they studied the effects of tra odour on catching Microtus townsendii. A further complication is that the very method of study can bias the results and hence four different trapping patterns were used. It is interesting to note that the type of trapping pattern did not appear to greatly affect the results obtained. Nevertheless, it is clear that if the results from just one or two studies are considered then very different conclusions can be made according to which studies are chosen.

The trap reaction of yellow-necked mice appears to have been most improved by prebaiting traps and indicates that further trapping studies on these animals, in Britain in particular, would be useful. Bank voles were more influenced by prebaiting traps than wood mice and in the latter case prebaiting for one night appears to have been equally if not more effective than prebaiting for two. The "prebaiting effect" was mainly lost by night two in wood mice, but by night three in bank voles. Gurnell (1976) has shown that wood mice quickly locate and utilise new traps placed on the ground, and the differences in trappability between the two species may result from differences in their exploration and penetration of the habitat, or from the fact that Apodemus spp. are known to dominate bank voles when they encounter each other (e.g., Andrzejewski \& Olszewski, 1963; Perrin, 1971).

The results show that prebaiting for one or two nights is only going to be beneficial if the trapping period is short, of the order of one or two nights. However. it should be pointed out that factors such as adverse weather can seriously affect the results from short trapping studies ( $\mathrm{T}$ a n ton, 1965). It has also been argued that prebaiting is necessary for estimating population size from short trapping periods (e.g. Ta nton, 1969, see S mith et al., 1975) but again in the case of wood mice it has been shown that capture-mark-recapture estimates of population numbers are of little value ( $\mathrm{Gurnell}$, 1972, 1976). Lastly, whether traps are prebaited or not, it has been shown that a substantial number of new animals are captured on the fourth night of trapping. It seems sensible, therefore to divert sampling effort away from 
prebaiting into trapping for several nights in order to obtain as much information as possible about the individual members of the population.

Many kill trap studies of woodland rodents have suggested prebait periods of five days or more (Gentry et al., 1968; Grodzinski et al., 1966). In addition to the above points there are two further possible consequences of extended prebait periods in live trapping studies. Firstly, bait could attract animals from outside the area (e.g., Pelik a n et al., 1972) and secondly unless fresh food and dry bedding are placed in the traps regularly, prebaiting could exacerbate trap deaths by animals eating all the food in the traps and making the bedding damp before trapping begins (see P e r r in, 1975). Quite a few animals died in the traps during the studies reported here and the combined results for all species are 62 deaths in $P_{2}$ traps, 40 in $P_{1}$ traps and 29 in $P_{0}$ traps $\left(\chi^{2}=12.9313, p<0.01\right)$; food was replenished but bediding was not replaced. One further point is that the trapping technique of the field worker must depend on the particular species being studied, and that as much as possible should be learnt about the trappability of that species; extended prebait periods may be necessary with some animals such as Common rats, Rattus norvegicus, or Grey squirrels, Sciurus carolinensis.

Acknowledgements: I am grateful to Professor P. A. Jewell and Dr A. M. Gurnell for their comments on the manuscript and the Forestry Commission for permission to work at Alice Holt Forest. Part of the work was carried out while I was in receipt of a grant from the Central Research Fund, University of London.

\section{REFERENCES}

1. Andrzejewski R. \& Olszewski J., 1963: Social behaviour and interspecific relations in Apodemus flavicollis (Melchior 1834) and Clethrionomys glareolus (Schreber 1780). Acta theriol., 7: 155-168.

2. Babińska J. \& B ock E., 1969: The effect of pre-baiting on captures of rodents. Acta theriol., 14: $267-270$.

3. B o onstra R. \& Krebs C. J., 1976: The effect of odour on trap response in Microtus townsendii. J. Zool., Lond., 180: 467-476.

4. Chitty D. \& Kempson D. A., 1949: Prebaiting small mammals and a new design of live trap. Ecology, 30: 536-542.

5. Gentry J. B., Golley F. B. \& Smith M. H., 1968: An evaluation of the proposed International Biological Program census method for estimating small mammal populations. Acta theriol., 13: 313-327.

6. Grodziński W., Pucek Z. \& Ryszkowski L., 1966: Estimation of rodent numbers by means of prebaiting and intensive removal. Acta theriol., 11: $297-314$.

7. Gurnell J., 1972: Studies on the behaviour of wild wood mice, Apodemus sylvaticus (L.) Ph. D. thesis, University of Exeter.

8. Gurnel1 J., 1976: Studies on the effects of bait and sampling intensity on trapping and estimating wood mice, Apodemus sylvaticus. J. Zool., Lond., 178: $91 \multimap 105$. 
9. Gurnell J., 1978a: Observations on trap response in confined populations of wood mice, Apodemus sylvaticus. J. Zool., Lond., 185: 279-287.

10. Gurnell J., 1978b: Studies on the reaction of wood mice to the normal treadle and a modified treadle in the Longworth trap. J. Zool., Lond., 186: $539-543$.

11. Kikkawa J., 1964: Movement, activity and distribution of the small rodents Clethrionomys glareolus and Apodemus sylvaticus in woodland. J. Anim. Ecol., 33: $259-299$.

12. Pelikan J., Zejda J. \& Holišova V., 1972: Influence of prebaiting on the catch of small mammals. Zool. Listy, 21: 209-225.

13. Perrin M. R., 1971: Exploratory behaviour as related to trapping results and population estimation in the vole, Microtus agrestis hirtus (Bellamy 1839). $\mathrm{Ph}$. D. thesis, University of Exeter.

14. Perrin M. R., 1975: Trap deaths. Acta theriol., 20: 167-174.

15. Smith M. H., Gardner R. H., Gentry J. B., Ka ufmann D. W. \& O'F a rrell M. H., 1975: Density estimations of small mammal populations. [In: "Small mammals: their productivity and population dynamics", F. B. Golley, K. Petrusewicz, L. Ryszkowski, eds.]. Cambridge University Press: 25-53, Cambridge.

16. Tanaka R., 1970: A field study of the effect of prebaiting on censusing by the capture-recapture method in a vole population. Res. Popul. Ecol., 12: $111-125$.

17. Tanaka R. \& Kanamori M., 1969: Inquiry into effects of prebaiting on removal census in a vole population. Res. Popul. Ecol., 11: 1-13.

18. Tanton M. T., 1965: Problems of live trapping and population estimation for the wood mouse, Apodemus sylvaticus (L.) J. Anim. Ecol., 34: 1-22.

19. Tanton J. T., 1969: The estimation and biology of populations of the bank vole (Clethrionomys glareolus (Schr.)) and wood mouse (Apodemus sylvaticus (L.)) J. Anim. Ecol., 38: 511-529.

20. Trojan P. \& Wojciechowska B., 1967: The reaction of small mammals to a new object and estimates of population numbers. Ekol. Pol., Ser. A., 15: $727-736$.

21. Zejda J. \& Holišova V., 1971: Quadrat size and the prebaiting effect in trapping small mammals. Annales Zool. Fennici, 8: 14-16.

Accepted, December 29, 1979.

John GURNELL

\section{WPEYW ZANĘCANIA NA ŁOWIENIE SIE GRYZONI LESNYCH W ŻYWOŁOWKI}

Przez trzy lata, w 15 różnych próbach badano wplyw zanęcania na łowienie się gryzoni w pułapki żywołowne typu Longworth (Tabela 1). Modyfikowano też sposób rozstawienia pułapek (Ryc. 1). Stwierdzono różnice w reakcji na pułapkę pomiędzy Apodemus sylvaticus, A. flavicollis i Clethrionomys glareolus. Choć lowienie się tych gatunków w przynęcane i nieprzynęcane pułapki różni się znacznie, to różnice są w większości nieistotne (Tabela 2). Wpływ przynęcania jest najlepiej widoczny u A. flavicollis, mimo niewielkiej ilości danych, a słabo wyrażony u A. sylvaticus (Ryc. 2 i 3 ). W zasadzie przynęcanie przez jedną noc jest tak samo efektywne jak przynęcanie przez dwie noce. Wyniki przedyskutowano w nawiązaniu do efektywności oznaczenia liczebności populacji. 